\title{
MIDAS
}

Museus e estudos interdisciplinares

$4 \mid 2014$

Varia e dossier temático: "Museus, utopia e urbanidade"

\section{Jesús-Pedro Lorente - Manual de Historia de la Museología}

\section{Ughetta Molin Fop}

\section{(Q) OpenEdition}

\section{Journals}

Edição electrónica

URL: http://journals.openedition.org/midas/640

DOI: $10.4000 /$ midas. 640

ISSN: 2182-9543

\section{Editora:}

Alice Semedo, Paulo Simões Rodrigues, Pedro Casaleiro, Raquel Henriques da Silva, Ana Carvalho

\section{Refêrencia eletrónica}

Ughetta Molin Fop, " Jesús-Pedro Lorente - Manual de Historia de la Museología », MIDAS [Online], 4 I 2014, posto online no dia 13 fevereiro 2015, consultado no dia 22 setembro 2020. URL : http:// journals.openedition.org/midas/640; DOI : https://doi.org/10.4000/midas.640

\section{Este documento foi criado de forma automática no dia 22 setembro 2020.}

\section{cc) (†) (-)}

Midas is licensed under a Creative Commons Attribution-NonCommercial-ShareAlike 3.0 International License 


\title{
Jesús-Pedro Lorente - Manual de Historia de la Museología
}

\author{
Ughetta Molin Fop
}

\section{REFERÊNCIA}

Lorente, Jesús-Pedro. 2012. Manual de Historia de la Museología. Gijón: Ediciones Trea. 112 páginas, ISBN: 978-84-9704-675-6.

1 Recolher num livro a história da museologia não é certamente uma tarefa fácil. De facto, a complexa evolução da disciplina faz-se através de um vasto conjunto de pessoas, de instituições, de associações, de teorias e de publicações, tornando muito complicado o trabalho de a condensar num único discurso. Um desafio que o professor universitário espanhol Jesús-Pedro Lorente (Universidade de Saragoça) superou nesta obra. O autor está ciente, no entanto, da impossibilidade de apresentar um texto exaustivo sobre esta matéria - sobretudo se a intenção é, como neste caso, contar a sua história a nível internacional. É portanto neste contexto que Lorente assume claramente na introdução do manual a intenção de «explicar sintéticamente las etapas de esa rica historia» (p. 11). Equilibrando um texto que se quer sintético, o autor opta por fornecer uma extensa bibliografia e muitos exemplos. Desta forma, o leitor pode apreender rapidamente a evolução histórica da disciplina, ao mesmo tempo que tem à sua disposição as ferramentas necessárias para aprofundar os temas que mais lhe interessam.

2 Logo com a leitura do índice ficamos com uma ideia clara do conteúdo e da estrutura lógica do livro. $O$ primeiro capítulo é dedicado à definição dos termos ligados a esta matéria. Do segundo até ao oitavo, Lorente traça a história da disciplina por períodos, destacando em cada fase os eventos, os protagonistas e as instituições mais relevantes. A escolha de começar por esclarecer os significados de museologia, de museografia e de museu reflete a intenção de clareza que caracteriza o manual. Um trabalho essencial, sobretudo numa área em que estes termos foram alvo de um prolongado debate até 
que, através dos esforços do Conselho Internacional de Museus (ICOM), se foram estabelecendo definições comuns. No entanto, é interessante notar que o autor nos permite refazer o caminho que o levou a este resultado, quer em termos geográficos, quer em termos temporais.

Lorente considera existirem três fatores cruciais para o desenvolvimento da museologia até à Primeira Guerra Mundial (segundo capítulo). O primeiro é o surgimento de publicações especializadas, o segundo, a criação de associações de profissionais, e o terceiro, a criação de cursos de formação. Naturalmente, esses três elementos estão diretamente relacionados, influenciam-se e enriquecem-se mutuamente e, não só são fundamentais neste momento inicial, como representam um elemento vital para toda a evolução da disciplina. É ainda graças a estes que, entre as duas guerras mundiais (capítulo três), surgem os primeiros cursos de museologia em diversas universidades do mundo e, em 1926, nasce a primeira organização internacional dedicada aos museus, o l'office Internationale des Musées (IOM). Após o revés causado pela Segunda Guerra Mundial, Lorente identifica vários fatores que, a partir de meados dos anos 40 e até ao início dos anos 70 (quarto capítulo), permitiram a revitalização e o fortalecimento de associações e estudos sobre museus. Em primeiro lugar, foi essencial a criação da UNESCO pela ONU, que foi decisiva em diversos aspetos, tais como a extensão do conceito de museu, a edição da revista Museum e a valorização dos museus em áreas do mundo que necessitavam de promoção. Em segundo lugar, na continuação do trabalho iniciado pelo IOM, é criado o ICOM, organização que foi inspirada pelas associações de museus, tais como a norte-americana ou a britânica. Com efeito, como o autor relembra, desde o início do século XX que as associações de museus aumentaram em número e exerceram uma grande influência através das suas conferências, publicações e boletins regulares. Em terceiro lugar, Lorente fornece numerosos exemplos de muitos países em que os cursos superiores de museologia ganharam nova vida e onde se iniciaram as primeiras pós-graduações; em seguida, o autor concentra-se no desenvolvimento de estudos de museus em países da Europa de Leste e afirma que, ao contrário do resto do mundo, «allí no era el objetivo prioritario capacitar profesionales de museos, sino articular un discurso disciplinar» (p. 49).

Já considerando o período a partir dos anos 70, o autor identifica mais um marco nesta área: o início da reivindicação da museologia como uma ciência (quinto capítulo). Essa tendência passa agora a não ser só característica dos estudos na Europa Oriental, mas também em outras áreas do globo, como a América Latina, os EUA, o Canadá e a Europa Ocidental graças sobretudo à consolidação ou ao nascimento de cursos universitários e respetivas publicações. Além disso, Lorente indica como novo impulso para a teoria dos museus, a criação, em 1977, do ICOFOM (Comité Internacional do ICOM para a Museologia).

O sexto capítulo é dedicado aos anos 80 , período em que começam a divulgar-se os estudos de nova museologia, já em alguns casos assumindo os seus significados atuais. A Nouvelle Muséologie, que se desenvolve em França, caracteriza-se pela introdução de novos estudos de museologia produzidos pelas novas experiências de ecomuseus e por uma nova comunicação e relação com a sociedade. The New Museology, no Reino Unido, concentra a sua atenção e interesse nos visitantes. Lorente caracteriza o início do século XXI (sétimo capítulo) pelo florescimento de novos modelos de museologia. Esta, como muitas outras disciplinas neste período histórico, é alvo de uma forte discussão interna, tanto na Europa, através de uma série de novas publicações teóricas, como em universidades americanas. Nestas últimas, em particular, desenvolve-se a chamada 
museologia crítica «dedicada al análisis de los museos pero con voluntad de producir impacto en la praxis» (p. 79).

5 Finalmente, para concluir a exposição histórica, o oitavo capítulo é dedicado à atualidade. Dada a grande quantidade de informações, não é possível mapear exaustivamente a situação internacional hodierna, mas o autor propõe uma longa seleção de títulos de publicações (incluindo uma menção à revista MIDAS) editadas pelos departamentos de centros universitários, museus, associações e editoras, muitas delas com hiperligações. Melhor do que qualquer outra descrição, esta lista demonstra a multiplicidade de possibilidades que uma pessoa interessada em museologia tem hoje à sua disposição para se formar, informar e atualizar.

6 No epílogo, o autor, em vez de oferecer um resumo ou breves considerações de conceitos já apresentados de forma clara, termina com «algunas pautas sobre que líneas de estudio pueden expandirse en el futuro» (p. 99). Desta maneira, Lorente não deixa o leitor apenas com um relato histórico, mas proporciona também algumas sugestões de tópicos de investigação que, na sua opinião, poderão marcar a museologia nos próximos anos.

O texto, em geral, proporciona uma leitura fácil, rápida e está bem estruturado. Além disso, facilitando o trabalho ao leitor, o autor preparou uma pequena lista de ideias principais e um resumo no início de cada capítulo. Ferramentas úteis tanto para ter um quadro introdutório daquilo que irá ser tratado, quanto para reencontrar facilmente alguns tópicos numa leitura futura.

7 Como é definido desde a introdução, o manual tem como objetivo «recordar el desarrollo diacrónico de las teorías museológicas, y de homenajear a algunas de las principales publicaciones, instituciones, asociaciones o personalidades que han marcado la evolución de la museología» (p. 11) e, certamente, consegue-o. De facto, uma das riquezas deste texto é oferecer um grande número de exemplos para todas estas categorias, às quais o autor decidiu prestar homenagem. Os diferentes exemplos e as referências ao contexto internacional são particularmente importantes por duas razões. Primeiro, é muito difícil encontrá-los reunidos num único manual. Em segundo lugar, raramente na Europa pensamos numa história da museologia fora das fronteiras da União Europeia ou da América do Norte.

8 Como já foi referido anteriormente, o manual é caracterizado pela síntese e, precisamente por esta peculiaridade, por vezes são omitidas algumas informações ou passagens que seriam úteis para uma rápida compreensão. Mas, na realidade, essas pequenas lacunas podem ser superadas facilmente graças à extensa bibliografia, que é um dos pontos mais fortes da publicação.

9 Por todas estas características trata-se de um texto útil para estudantes e amadores que queiram aproximar-se do mundo da museologia. Mas, por outro lado, não deixa de ser uma leitura útil a especialistas na área. Com efeito, o livro oferece várias pistas $\mathrm{e}$ referências bibliográficas de textos e publicações online, suficientemente numerosas para permitir quer um primeiro contacto com o tema, quer um aprofundamento de conhecimentos dentro da área. 


\section{AUTORES}

\section{UGHETTA MOLIN FOP}

Instituto de História da Arte, Faculdade de Ciências Sociais e Humanas, Universidade Nova de Lisboa, Portugal, ughettamolinfop@gmail.com 